\title{
Child Abuse in Toni Morrison's Fiction
}

\author{
R.M.Prabha \\ Ph.D. Scholar, Manonmaniam Sundaranar University, Tirunelveli, Tamil Nadu \\ prabharmk@gmail.com
}

\begin{abstract}
Child abuse is when a parent or caregiver, whether through action or failing to act, causes injury, death, emotional harm or threat of serious harm to a child. There are four main types of child maltreatment, including neglect, physical abuse, sexual abuse, and emotional abuse. The theme of 'Child Abuse' is seen abundantly in Toni Morrison's novels. The real brunt and burden that comes as a result of abuse of children can be intolerable. The victims suffer the most. They lose their sense of survival and may go insane. Toni Morrison emphasizes the importance of recognizing and exploring this disastrous evil of 'Child Abuse' in order to prevent it. 'Child Abuse' results in the development of a psychological barrier that prevents the normal development of the child. Abuse destructs the tender self and mind. Child abuse in her novels has devastating outcomes when compared to the results of maternal child murders seen in her novels. This paper analyses the child abuses in Morrison's novel and the way it affects the community. It is child abuse that causes more trauma to the self and could result in complete extinction of one's mind. The paper categorizes the abuses of children by Morrison's mothers and discusses the behavior of the abusive mothers who are factual murderers of 'self.' The paper also analyses the effects of such abuse in the lives of the victims and as well as others around them.
\end{abstract}

Keywords: Abuse, neglect, child, molestation, trauma.

\section{INTRODUCTION}

According to Marianne Hirsch, Morrison's mothers consider their children as an extension of their limbs and wounds to express the bondage of their relationship [1]. Marianne quotes Toni Morrison's words in Sula: "Their [Mothers] children were like distant but exposed wounds whose aches were no less intimate because separate from their flesh" (Sula 122).

However, in Toni Morrison's fiction there is a surfeit of 'child abuse' strewn all around her eleven novels. They seem to cause more trouble to the minds of the readers. Child abuse or child maltreatment is any act, or failure to act, by a parent or other caregiver that results in actual or potential harm to a child. The World Health Organization defines child maltreatment as: "all forms of physical and/or emotional ill-treatment, sexual abuse, neglect or negligent treatment or commercial or other exploitation, resulting in actual or potential harm to the child's health, survival, development or dignity in the context of a relationship of responsibility, trust or power" [2]. Child abuse falls into one or more of four categories: Physical abuse, Emotional abuse, Sexual abuse and Neglect.

When humans are young, they are absolutely depending on their caregivers. Their world revolves only around their parents or primary care-givers. Parents or caregivers are the primary source of safety, security, love, understanding, nurturance, support and sustenance. Child abuse violates the trust at the core of a child's relationship with the world [3]. As the crucial relationship with the primary caregivers becomes one of betrayal, the child's thought becomes irreversibly altered. Betrayal results in the development of a negative schema and set of beliefs. This negative core schema often affects an individual's ability to establish and sustain significant attachments throughout life. Survivors often experience conflicting relationships and disordered lifestyles. They frequently report difficulties forming adult intimate attachments and display behaviors that threaten and disrupt close relationships [4]. The brain develops at an incredible pace during the early developmental stages of infancy and childhood. Various studies on 'Early Childhood Development,' indicates that the brain and thoughts of the child develops in response and as a reaction to experiences with caregivers, family and the community. The development is directly linked to the quality and quantity of those experiences. It is mandatory that a child's need be met during the early stages as it creates emotional 


\section{R.M.Prabha}

stability and security that is needed for healthy brain development of the child. Repeated acquaintances with stressful incidents will affect the brain's stress response, making it more reactive and less adaptive. The brain becomes more irritable and sensitive. With time, a child may react as if danger is always present in their environment regardless of what the presenting situation actually are [5].

Research has found that children exposed to violence or abuse, if left unaddressed or ignored, are at an increased risk for emotional and behavioral problems in the future [4]. Children who are abused may not be able to express their feelings safely and as a result, may develop difficulties regulating their emotions. As adults, they may continue to struggle with their feelings, which can lead to depression or anxiety [5].According to U.S statistics, one in 10 children suffers from child maltreatment. One in 16 children suffers from sexual abuse. Nearly one in 10 children is a witness to family violence. The youngest children are the most vulnerable and are susceptible to maltreatment. Over $25 \%$ of abused children are under the age of three while over $45 \%$ of abused children are under the age of five. There has been an overall increase in the number of abuse and neglect substantiations [6].

\section{Physical Abuse}

Physical abuse often does not occur in isolation, but as part of a constellation of behaviors including authoritarian control, anxiety-provoking behavior, and a lack of parental warmth. The WHO defines physical abuse as: Intentional use of physical forces against the child that results in or has a high likelihood of resulting in - harm for the child's health, survival, development or dignity. This includes hitting, beating, kicking, shaking, biting, strangling, scalding, burning, poisoning and suffocating. Much physical violence against children in the home is inflicted with the object of punishing [2].

In the novel Tar Baby by Toni Morrison, Margaret, a young mother abuses her child physically. She burns her son as an infant with cigarette tips and pricks him with pins. Margaret's maternal shortcomings are only hinted at during the course of the novel. Morrison says, "When he was an infant he seemed to want everything of her, and she did not know what to give. She loved him even then. No one would believe it. They would think she was one of those mothers in the National Enquirer" (Tar Baby 58). At the heart of Margaret's problems are issues of society and status, as she would appear to be the embodiment of what women should want to be, but she is self-destructive. Margaret loses a sense of self as she struggles to fit into an upper class that she is not born into, and she is constantly defeated because of her family's lack of contribution to her development and her husband's constant criticism. She is treated as an object because of her beauty.

For Margaret, nothing could really "explain" her weird behaviors when she was young. Certainly, as a young woman she was deeply unhappy, married to a man much older than she and living in a place far from home where she did not fit in. She felt bored and probably hopeless, without anything meaningful in her life. What caused her to take out her frustrations in such a horrendous way, however, must remain a mystery. A mother, who deliberately harms her own child, while convincing herself that he did not suffer much, needs psychological help, which was something Margaret, isolated on the Isle des Chevaliers, and never had any hope of receiving.

The effects of this abuse bring many changes in the family of Valerian. In addition, it had a huge implication on the victim, Michael. Michael had become a Socialist. When he was thirty Michael seems to be more worried and concerned about the problems of the oppressed, dispossessed and the environment. Since he is a boy, he copes well to come out of the abusive environment during his childhood and does not drift into insanity. He makes a career for himself out of other people's pain. His adult life is a direct reflection of the problems he faced as a child. As an infant, his tender mind is partially destructed by his caretakers and thoughts were confabulated by the environment. Remembering Michael as a child, Valerian is amused about his son's need for soft things,

When he was just a little thing I came home one day and went into the bathroom. I was standing there and I heard this humming - singingcoming from somewhere in the room. I looked around and then I found it. In the cabinet. Under the sink. He was crouched in there singing. That was the first time, but not the last. Every now and then I'd come home, he'd be under the sink. Humming to himself. When I'd pull him out, ask him what he was doing there, he'd say he liked the soft. He was two, I think, two years old, looking in the dark for something-soft. Now imagine how many soft, cuddly things he had in his room (Tar Baby 76). 
After Michael grows up, he escapes the awful wraths of abuse. He is one among the very few victims who manage a life after the abusive period. According to Valerian, Michael as a young man now, is always complaining and 'mewing' about the problems of the suppressed. Though in Tar Baby, the abused child escapes destruction, it is not the case always. Valerian stresses the importance of motherhood by saying that mother is not the person one could not chose not to love. He says,

I have to cry blood tears for his wounds. But I will need several lives, life after life after life after life, one for each wound, one for every trickle of blood, for every burn. I will need a lifetime of blood tears for each one of them. And then more. Lives upon lives upon lives for the the the the the Hurt. The deep-down eternal little boy hurt. The not knowing when, the never knowing why, and never being able to shape the tongue to speak, let alone the mind to cogitate how the one person in the world upon whom he was totally, completely dependent - the one person he could not even choose not to love-could do that to him. (Tar Baby 218)

Valerian is in great pain and sits in his greenhouse thinking about the time he found Michael hiding under the sink. After the Christmas dinner, Margaret tried to explain her behavior to Valerian, but she sickened him when she told him that she abused Michael because it felt delicious. After the confession by Margaret, the family never had any peace or union. Margaret started showing signs of incoherence and confusion. Morrison says, "She can mistake a stick of celery for a knife or pour water from her glass instead of gravy over the prime ribs" (Tar Baby 61). This suggests that probably, Margaret suffered some form of a psychiatric illness from the beginning, which had manifested in child abuse. Her behavior must have been worsened by her loneliness and neglect by Valerian.

When Margaret becomes fifty, she suffered from aphasia and has a perception disorder. When she was young, she may have been harboring the prequel of her mental illness. The unique hostile environment, in which she lived, compounded her mental illness. She was lonely in the urbanized palace of Valerian. There was no true love at home. As with all forms of abuse, one of the main reasons an abuser becomes abusive is because he or she was once abused. In addition to that, the stress, worry, isolation and helplessness that can overcome a parent can contribute to abusive tendencies. Parents who did not get enough time for adequate self-care, and parents who are not aware of appropriately and consistently disciplining a child, have a huge propensity to develop abusive tendencies. Substance abuse and addictions can be the root cause or can simply exacerbate the problem. Margaret also was involved in substance abuse, tobacco. According to the National Center on Addiction and Substance Abuse at Columbia University estimates in a 2005 report, substance abuse is a factor in at least 70 percent of all reported cases of child maltreatment. Adults with substance abuse disorders are 2.7 times more likely to report abusive behavior and 4.2 times more likely to report neglectful behavior towards their children. Maltreated children of substance abusing parents are more likely to have poorer physical, intellectual, social and emotional outcomes and are at greater risk of developing substance abuse problems themselves [7].

\section{SeXual AbuSe}

Sexual abuse occurs when an adult uses a child for sexual purposes or involves a child in sexual acts. In The Bluest Eye, father of Pecola, Cholly is often drunk and beats his wife and children. He rapes his own daughter, Pecola, and as a result, she becomes pregnant with his child. Cholly is notorious for his indiscipline and awkwardness. In one of his drunken stupors, he lights his own house on fire and burns it down. He is a dreadful father to both his kids. He neither shows love towards his family nor is available to listen to their problems. He is absent most of the times. His blackness angers him, eventually leads him to believe he is ugly and disagreeable. He strongly believes that he does not deserve a better life. He always uses his anger negatively by hurting those around him.

Pecola is an easy prey to Cholly because she is a child and has no power or control over adults. She is a female and no knowledge has been imparted to her to oppose any form of oppression. Eventually, Pecola has to face sexual abuse at the hands of her father Cholly. He rapes her twice. She is forced to participate in a horrendous sexual act, which is just intended towards the physical gratification of her father. He rapes her regardless of the outcome. He is more powerful than Pecola, so makes her the victim. This is a form of incest, which leaves Pecola in a psychological trauma. Cholly's rape results in impregnating Pecola. The whole community, both the blacks and whites starts to hate her for 


\section{R.M.Prabha}

carrying her father's baby. Social stigma of Pecola's sexual abuse compounds her psychological harm. By raping Pecola, her father has killed her infinite number of times. Her mother Pauline neglected Pecola's complains to her and beat her. By neglecting her and not consoling her, Pauline indirectly made Pecola die an infinite number of times.

Seneca in the novel Paradise, is also an abandoned girl. She is abandoned by her mother at a very early age and she starts to live a lonely life. Both her mother and sister have abandoned her, until child services discovered her and put her into foster care. In the foster house, her stepbrother starts to sexually abuse her. She is tormented by physical and sexual abuse at her early life. This transforms her into a neurotic. Her behavior becomes weird and she does not accept and adjust easily with others. She becomes an introvert. She escapes torture during her time in foster care by self-mutilation and she believes it garners positive attention. She becomes a neurotic and self-harms her by cutting her forearm during times of distress. Seneca is the 'Pecola' of Paradise. The character Consolata in the novel Paradise also experiences childhood abuse, and was later rescued by Mary Magna at the age of nine. A similar character, Sorrow, in the novel A Mercy also suffers sexual abuse at her foster family, who rescued her after a shipwreck. She is portrayed to be in the state of a pitiful mongrel, who is violated by all means. She is the 'Pecola' of A Mercy.

Rain in the novel God Help the Child also experiences sexual abuse and molestation through her mother. Rain even before the age six had to endure atrocious life because of her mother, who is a prostitute. Hannah is another character in the same novel and is abused by her father. She is the daughter of Queen, Booker's aunt. Hannah is molested by her own father, which Queen was not ready to accept. Later, she understood the issue and forever was sorry for her negligence and repented until her death. However, she failed like Pauline to act in the appropriate time. Queen had many husbands and was blind to see her daughter suffer. Queen, "was rumored to have had many husbands - one a Mexican, then two white men, four black men, one Asian, but in a sequence no one recalled" (67).Once, Booker says of Hannah to Bride, "There was a thing with Hannah. Rumor in the family was that Queen ignored or dismissed the girl's complaint about her father-the Asian one, I believe, or the Texan. I don't know. Anyway she said he fondled her and Queen refused to believe it" (God Help the Child 91). Both Rain and Hannah are the 'Pecolas' of the novel God Help the Child.

\section{NEGLECT}

Child neglect is when a parent or caregiver does not give the care, supervision, affection and support needed for a child's health, safety and well-being [2]. Child neglect includes:

- Physical neglect and inadequate supervision

- Emotional neglect

- Medical neglect

- Educational neglect

Many of Morrison's mothers readily neglect their own children. Around20 mothers in her eleven novels do not bother much in rearing their own children. Either they leave them stranded soon after birth, or they may abandon them when they are toddlers. There are mothers who neglect their children when they are adolescents. Cholly's mother in The Bluest Eye abandons him soon after birth. His life is negatively impacted by his inability to identify with his ancestral past. Cholly is abandoned by his father before his birth and abandoned by his mother nine days after birth. Cholly's great aunt says about his mother, "Your mama didn't name you nothing. The nine days wasn't up before she throwed you on the junk heap" (The Bluest Eye 133).Pallas' mother in Paradise neglects her daughter in adolescence. Seneca's mother in Paradise abandons her when she was five years old. Seneca completely lacks self-confidence and always tries to please others. Hannah in Sula and Pauline in The Bluest Eye do not care about their daughters. In Morrison's last novel, many mothers are seen to be neglecting their children. Child abuse grazes a sharp scar through Toni Morrison's God Help the Child. The novel is a brisk modern day tale with shades of the imaginative cruelties visited on children. The novel has a blunt moral; "What you do to children matters. And they might never forget." 
The protagonist of the novel is a young black girl, Bride. Bride had a difficult childhood as both her parents neglected her. Bride is portrayed as a young, beautiful girl, with deep blue-black skin and she has a job in the cosmetics industry. Her light-skinned mother, Sweetness, rejected her as a child. Sweetness has been poisoned by the strain of color and class anxiety still present in black communities [8]. She says, "It didn't take more than an hour after they pulled her out from between my legs to realize something was wrong. Really wrong. She was so black she scared me. Midnight black, Sudanese black" (God Help the Child 1). Because of her dark color, Bride's father, Louis assumes that she is not his baby, never touches her, and eventually leaves Sweetness, after three years of marriage, to raise Lula Ann (Bride) on her own. Sweetness is embarrassed to be seen with such a dark child. She treats her harshly from the beginning and does not even want to touch the baby, a feeling she has throughout Lula Ann's whole life. However, Sweetness claims to believe that she is only doing this to help the child, to toughen her up and make her strong, so she will not fall prey to bullies and discrimination. Since she is ashamed for people to think that Lula Ann is her child, she tells the baby to call her "Sweetness" instead of "Mama" or "Mother." Sweetness sees Lula Ann's color as "a cross she will always carry" and professes over and over that Lula Ann's plight in life is not her fault.

Bride's father is also unwilling to accept the child's dark skin and walks out on the family, accusing Sweetness of infidelity. Therefore, Bride grows up, pinched by hunger and shame, craving love and acceptance. Bride was affected by her mother's neglect at a very early age. When she was old, she remembers that her mother did not like to even touch her. She says, "I always knew she didn't like touching me. I could tell. Distaste was all over her face when I was little and she had to bathe me" (God Help the Child 23). She continues, “... Rinse me, actually, after a halfhearted rub with a soapy washcloth. I used to pray she would slap my face or spank me just to feel her touch. I made little mistakes deliberately, but she had ways to punish me without touching the skin she hated - bed without supper, lock me in my room" (God Help the Child 23).

There are many children in "God Help the Child," and they all suffer from some form of abuse. The protagonist of the novel, Bride, is rejected by her mother because of her skin tone. Rain, is an almost feral child who is prostituted by her mother. Rain was abused and molested as a child. When she was six years old, she was thrown out of her home. Her mother was aprostitute herself who did not care for her daughter. When Rain opposed, she threw her out of home. Rain confides in Bride what her life was like before she came to live with Steve and Evelyn. Her biological mother allowed men to use and abuse her sexually for money. Although Bride was never sexually assaulted, she realizes the scars that her abuse has placed on her and is horrified to hear what Rain has gone through in her short life so far. Out in the streets, Rain describes her tough life to Bride,

You had to find out where the public toilets were.... how to avoid children's services, police, how to escape drunks, dope heads. But knowing where sleep was safe was the most important thing. But knowing where sleep was safe was the most important thing. It took time and she had to learn what kinds of people would give you money and what for, and remember the back doors of which food pantries or restaurants had kind and generous servers. The biggest problem was finding food and storing it for later." (God Help the Child59)

Neglect is also seen in Toni Morrison's Sula, where the character Sula is seen to be not cared well by her mother Hannah. Hannah was bothered only about her own pleasures and she sort of neglected Sula. Once she says of Sula that, "I love Sula. I just don't like her" (Sula 59).Sula experienced this kind of emotional neglect in her life.

\section{Emotional AbUSE}

Emotional abuse refers to the psychological and social aspects of child abuse. It is the most common form of child abuse. Many parents are emotionally abusive without being violent or sexually abusive. When a parent or caregiver harms a child's mental and social development, or causes severe emotional harm, it is considered emotional abuse. While a single incident may be abuse, most often emotional abuse is a pattern of behavior that causes damage over time. Some parents who are emotionally abusive parents practice forms of child raising that are focused towards gratifying their own desires and goals, rather than those of their children. Their nurturing style may be characterized 
by blatant hostility towards their children, including shouting, yelling, bullying and intimidation, or they may manipulate their children using more subtle means, such as emotional blackmail.

Pauline of The Bluest Eye is one example of this type. Pecola has never been taught anything about her body by her mother. She does not have any liberty and right to ask any personal questions to her. Thus, her transition to adulthood becomes difficult and traumatic. In fact, Pecola's mother has never treated her as a human being and loved her to teach her womanhood. Claudia says, "Adults do not talk to us. They give us directions. They issue orders without providing information" (The Bluest Eye 13). Children do not have the courage to question the adults. Claudia further writes about her [Pecola] mother, "It was certainly not for us to dispute her. We didn't initiate talk with grownups; we answered their questions (The Bluest Eye23). These words from Claudia obviously reveal the relationship between Pauline and her children.

\section{EFFECTS ON CHILDREN WHO WiTnESS DOMESTIC ViOLENCE}

The emotional toll on children who witness threats or violence against others can be considerable, especially when those involved are familiar to the child and the violence takes place in the home. Current research has found that children exposed to domestic violence are at an increased risk for emotional and behavioral problems, including anxiety, depression and academic problems [7]. In Morrison's fiction, Pecola and her brother witnessed domestic violence all day and night at their home. Violence was such that, there was continuous fight between Cholly and Pauline. They constantly used to abuse each other without caring about the presence of their children. There was not a single day without fight. Pecola's brother soon ran away because of the state of his family. He is known to run away. He has left more than twenty-seven times before he was fourteen years old. Pecola on the other hand, being younger than Sammy and also a girl, tries different methods of survival. Pecola tried to be with the family, which later proved fatal for her. Had she been out of her family, at least her father would not have raped her to make her mad. Besides this, Cholly has a habit of sleeping naked and he does not care that his children knows about it. This is a form of awful domestic violence. One of the fights that were triggered by Cholly's negligence in bringing coal for the stove ends in Pauline's picking up the stove lid and knocking him right back into the senselessness out of which she had forced him (The Bluest Eye43). Cholly and Mrs. Breedlove fought each other with

A darkly brutal formalism... Tacitly they had agreed not to kill each other. He fought her the way a coward fights a man-with feet, the palms of his hands, and teeth. She, in turn, fought back in a purely feminine way-with frying pans and pokers, and occasionally a flatiron would sail toward his head. They did not talk, groan, or curse during these beatings. There was only the muted sound of falling things, and flesh on unsurprised flesh. (The Bluest Eye 43)

Subsequently, Sammy starts to hit his father on the head with fists shouting -'You naked fuck! Over and over and over" and encouraging his mother with, "Kill him! Kill him!" (The Bluest Eye43).Hence, Children are affected when they witness domestic violence, regardless of whether or not they are directly abused. Children's responses may depend on the severity and frequency of the abuse, the availability of family and community support, and the child's resilience.

\section{DisCuSSION}

Toni Morrison seems to be frustrated with the undue suffering that abused children have to undergo. Morrison started her mission by writing her first novel, which is all about the abuse of an eleven-yearold girl, Pecola, who finally succumbs to the abuse by becoming insane. In her eleventh novel, there are many 'Pecolas,' to suggest that the problem is too much to bear. Child abuse, by itself relates only to the primary caregivers/ parents. However, abuse of a child by an outsider will be a criminal offence. Initially, Morrison was talking about child abuse from inside the family. In her latest novel, there are many illustrations of criminal offence against children. She portrays many child victims in the novel, God Help the Child, to intensify the gloomy mood in the novel. In some ways, her latest work is reminiscent of Morrison's debut novel, "The Bluest Eye." In The Bluest Eye, also the children endure the most of all of society's illnesses. They are the truest victims of poverty and racial prejudice. 
In the beginning of her latest novel, there is an anonymous little boy, whose rape Bride witnesses as a child and she is unable to stop. This is an example for criminal offence, which goes unaddressed. Child abuse or molestation first comes into play in the novel as Bride recalls testifying at the trial of a teacher at her school who is accused of molesting some children. However, Sofia Huxley, the accused is an innocent woman. Bride accuses her of a terrible crime to get her mother's attention. Bride, immature and starved for mother's love does this when she was too young to realize about the consequences. However, all other perpetrators of child abuse in the novel are all real. Child molestation becomes the topic of the novel as Bride remembers telling Booker the memory of seeing her landlord molesting the anonymous young boy. When Bride told Sweetness about what she saw, Sweetness got mad about the story of what the man did to the boy and was upset that Lula Ann may tell someone which would make trouble for them and cause them to need a new apartment. As far as Bride knows now, there has been no justice for that boy. She realizes as an adult how guilty she feels about not helping him or telling someone what had happened.

Many other characters and their stories carry on the motif of child molestation and abuse. In Booker's case, the abuse happens to his brother who ends up murdered. Adams predator was wrongly considered a nice man around the community. He was an auto mechanic by profession and was known to be a good man. Here Toni Morrison warns the world about the degree of deception anybody can carry with them to fool others. What might look good may be absolutely wrong. Six years after the death of Adam, the killer was caught. He had molested and killed six young boys in the locality in a brutal way. Six years later when Booker was fourteen, "the nicest man in the world was caught, tried and convicted of SSS, the sexually stimulated slaughter of six boys, each of whose names, including Adam's, was tattooed across the shoulders of the nicest man in the world. Boise. Lenny. Adam. Matthew. Kevin. Roland" (God Help the Child 67). Apparently, the children were kept bound while molested, tortured and there were amputations. This is the kind of criminal offence that is seen rampantly now all over the world. Perversions, drugs, violence, rage and brutality has become the core of mankind. Toni Morrison has repeatedly talked about children's suffering in her latest novel.

Because of the tragedy of Adam's murder, Booker is affected in many ways. The theme of 'Overcoming One's Childhood Trauma' is prominent in Booker's life. Adam's murder continues to affect him throughout his life. He beats a man on a playground by his college when the man exposes himself to the children. Later, he beats another man who is doing drugs with a woman in the front seat of a car while a baby cries in the backseat. The couple were, "taking turns sucking on a crack pipe." He noticed, "A child, maybe two years old, screaming and crying while standing in the backseat of the crack heads' Toyota." (God Help the Child 72). He seeks to right the wrongs of men who are inappropriate with children because of the torture, pain, and death that Adam endured from the man who took him so many years ago. What happens to Booker's brother in their childhood shapes the adult that Booker becomes. He is the ever-vigilant watcher of indecency to or in front of children. In Hannah's case, she must live with and overcome the fact that not only did her father sexually abuse her, but also her mother did not believe her nor did she do anything to investigate or change the situation.

The character of the perpetrators of child abuse also varies from each other. There are five known risk factors in families prone for child abuse. They are the domestic violence, drug abuse, mental illness, lack of parenting skills and stress [9]. It is only Margaret in Tar Baby who must have had a mental illness for her to periodically abuse her child physically. The other mothers who abused and neglected their children were all mentally stable. Pauline had difficult times when she was young, but was mentally stable. Pauline lacked parenting skills and was stressed due to self-loathing and her unstable husband. In addition, there was domestic violence at the household of the Breed loves' family. Sweetness was normal like any woman. She just lacked parenting skills. Seneca's mother and the mother of Connie in Paradise left them in the streets abandoned. Rain's mother was a prostitute. They probably were drug abusers. The foster parents of Seneca abused her sexually and physically. These women could have been much better women and could have acted a lot better. If not for Cholly's sexual abuse and Pauline's neglect, Pecola could have been saved. Hannah was selfish and cared only about her own pleasures. She neglected Sula and was responsible for her eccentric behavior.

The victims of abuse suffer tremendously in all aspects. The effects of abuse could be long lasting. It could damage a child's sense of self, ability to have healthy relationships, and ability to function at home, at work and at school. They lose trust, feel worthless and have trouble regulating emotions 


\section{R.M.Prabha}

[9].Either they become insane or they carry the pain all throughout their life with an impaired mind. The abused children in Morrison's fiction suffer enormously and their pain is unrelenting. When such children grow into adults, the suffering they endured during their childhood days manifests in its own ways. Eventual outcome can be devastating and includes a broken mind with breaking up of families and individual 'self'. Valerian's family is broken and all their lives come to a standstill because of what happened to Michael. Child abuse can make a person's life meaningless by breaking the individual 'self' pushing them into an irreparable state. Pecola drifted into insanity. Child abuse also results in unstable mind that ends up in economic losses, where characters lose their job and living in many ways. They lose their inner peace and lose control over their life. Seneca became neurotic and started abusing her own body physically. It is not only them who had to suffer, but also the community. It becomes as a major hindrance to the prosperity of the whole community. Child abuse is equal to extinguishing life and peace on earth. According to Morrison, child abuse may be the greatest evil in the world. The worry is the magnitude of the problem is on the rise.

\section{CONClusion}

Toni Morrison has written eleven novels so far. The first ten novels had lot of accounts on the issue of child abuse. However, in the latest novel God help the child, Child molestation and abuse forms the primary theme of the novel. Many characters in the novel were abused / molested. Toni Morrison seems to be so much disturbed by the issue that she talks about it so much in her latest novel. Even the title of her latest novel has the word, 'Child' in it and is such that one is asking help for the abused children. It is like asking 'God' to help the suffering children. It is a novel written to arouse awareness about child abuse. In her first novel, a child drifts into insanity because of abuse. In her latest novel, many children were abused, whose fate is uncertain. The magnitude of the problem has been growing steadily with urbanization and modernization of the world, which has discarded ancient values and culture. The natural barriers of protection for progeny of humankind are all damaged and removed by the modern man. The modern man's mind is becoming more and more mechanical than biological. Women and men are more worried about their own self than their children and community. Selfishness, timelessness, modernization and urbanization, all have killed the protective culture and have engulfed the natural protection that was mandatory for the growth of a child. Man has gone wild. This fact is so disgusting for Toni Morrison that she has talked about it repeatedly from 1970, since the publication of her first novel and has addressed the issue directly in depth in her latest novel, published in 2015. She ponders over the issue, instructs people the way to live. She points out the presence and emergence of this particular social evil. She warns the society to have insight and ways to fight against the evil. In her latest novel, her motto is, "What you do to children matters. And they might never forget." Hence, in Morrison's fiction, Child abuse rings an alarming bell for the readers to watch for and to strive to bear a good responsibility to protect vulnerable children. Hence, a caretaker abusing a child merely equals to killing the child an infinite number of times. Toni Morrison can rightly be called as an 'Author for Children.'

\section{WORKS CITED}

\section{Primary Source}

Morrison, Toni. Beloved. London: Vintage Books, 1987. Print.

- God Help the Child. London. Vintage Books. 2015. Print.

- Paradise. New York: Plume, 1999. Print.

- Sula. London: Vintage Books, 1973. Print.

- Tar Baby. London: Vintage Books, 1981. Print.

— The Bluest Eye. London: Vintage, 1970. Print.

\section{Secondary Source}

[1] Hirsch, Marianne. The Mother / Daughter Plot: Narrative, Psychoanalysis, Feminism. Bloomington, IN: Indiana UP, 1989. Print.

[2] World Health Organization and International Society for Prevention of Child Abuse and Neglect (2006). "The nature and consequences of child maltreatment". Preventing child maltreatment: a 
guide to taking action and generating evidence (PDF).ISBN 9241594365.Geneva, Switzerland: WHO Press, 2006. Print.

[3] Walker, L.E.A. Abused women and survivor therapy: A practical guide for the psychotherapist. Washington, DC: APA Press. 1994. Print.

[4] Henderson, Corinne. Reframing Responses: Improving Service Provision to Women Survivors of Child Sexual Abuse who Experience Mental Health Problems Mental Health Coordinating Council Victims of Violent Crimes Grants Program. Lily field, New South Wales: 2006.

[5] Stien, Phyllis T. and Kendall, Joshua. Psychological Trauma and Developing Brain: Neurobiological Based Interventions for Troubled Children. New York: The Haworth Maltreatment and Trauma Press, 2004. Print.

[6] U.S. Department of Health and Human Services, Administration for Children, Youth, and Families .Child Maltreatment 2007. U.S. Government Printing Office; Washington, D.C: 2009.

[7] Child Welfare Information Gateway, "Long-Term Consequences of Child Abuse and Neglect," Factsheets, (2008). Web: May 2016. www.childwelfare.gov.

[8] Sunday Book Review. Toni Morrison's 'God Help the Child' KARA WALKER. April 13, 2015.

[9] Smith, Melinda and Segal, Jeanne, "Child Abuse \& Neglect: Recognizing, Preventing, and Reporting Child Abuse.” Web: June 2016.www.helpguide.org.

\section{AUTHOR'S BIOGRAPHY}

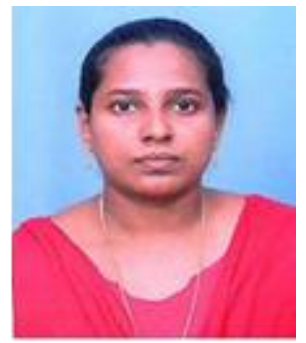

R.M.Prabha, is a research scholar, currently pursuing her Ph.D. course at the Manonmaniam Sundaranar University in Tirunelveli. Her main area of interest is fro-American literature. She has extensively done research on the Afro-American author Toni Morrison and her novels. She completed her undergraduate [B.A English] degree course at the Govindammal Aditanar College for Women in Tiruchen during2006. She did her Master's degree in English [M.A] and subsequently M. Phil. degree in Sarah Tucker College for Women in Tirunelveli. After her graduation she has served the college in which she did her undergraduate degree, as a faculty, Assistant Professor in English forn early four years. Her project for her M. Phil degree was on the novel Jazz by Toni Morrison. Her current research work also involves Toni Morrison's select novels. 